\title{
The reciprocal relationship between primordial germ cells and pluripotent stem cells
}

\author{
Mehdi Pirouz • Alexander Klimke • Michael Kessel
}

Received: 20 February 2012 /Revised: 3 April 2012 / Accepted: 2 May 2012

(C) Springer-Verlag 2012

\begin{abstract}
Primordial germ cells (PGCs) are induced in the epiblast early in mammalian development. They develop their specific fate separate from somatic cells by the generation of a unique transcriptional profile and by epigenetic modifications of histones and DNA. PGCs are related to pluripotent cells in many respects, both on a molecular and a cell biological level. Mimicking their in vivo development, PGCs can be derived in culture from pluripotent cells. Vice versa, PGCs can be converted in vitro into pluripotent embryonic germ cells. Recent evidence indicates that the derivation of pluripotent embryonic stem cells from explanted inner cell mass cells may pass through a germ cell-like state, but that this intermediate is not obligatory. In this review, we discuss PGC development and its relevance to pluripotency in mammalian embryos. We outline possibilities and problems connected to the application of in vitro-derived germ cells in reproductive medicine.
\end{abstract}

Keywords Primordial germ cell · Pluripotent stem cell · Epigenetics · Pluripotency · Reproductive medicine

\section{Introduction}

Germ cells are unique cells present in vertebrates during almost the entire life span. Their task is to carry the genetic material safely into the next generation. For that, they develop separately from all other cells of the body, and probably their genomes undergo particularly critical quality controls. In this

M. Pirouz $\cdot$ A. Klimke $\cdot$ M. Kessel $(\bowtie)$

Department of Molecular Cell Biology,

Max Planck Institute for Biophysical Chemistry,

37077, Goettingen, Germany

e-mail: mkessel1@gwdg.de review, we concentrate on the mouse as a model system, which was most intensely studied in terms of cell biological, genetic, and molecular aspects. It can be assumed that the principal findings for mice apply also to other mammalian species including humans, while lower vertebrates like fishes and some amphibians differ significantly in early mechanisms of germ line development.

Primordial germ cells (PGCs) arise early in embryogenesis and develop further in the genital ridge at midgestation, whereas the male and female gametes are only formed after birth. The germ cell cycle is finished by the fusion of an oocyte with a spermatozoon, giving rise to a diploid one-cell embryo [1]. During the first cell divisions of a mouse embryo, there is no separate development of somatic cells from the germline. Only at the onset of gastrulation a small set of PGC progenitors is induced in the epiblast in response to instructive bone morphogenetic protein (BMP) signals [2-4]. The first bona fide germ cells, the PGCs, leave the epiblast with the extraembryonic mesoderm at the posterior primitive streak, and thus, in mice, a group of around 40 PGCs locates at the base of the allantois. From here, the PGCs migrate within the definitive endoderm of the prospective hindgut during early organogenesis, exit from the hindgut endoderm, and migrate via the dorsal mesentery towards the genital ridges. Here, they accumulate in the gonad anlagen, and ovaries and testes become morphologically distinguishable around midgestation [5-8]. Murine PGC precursor cells in the epiblast divide very rapidly with a doubling time of 5-7 h, comparable to their surrounding cells [9-11]. However, they slow down drastically to a regular 16-h cell cycle after translocation from the epiblast to the extraembryonic mesoderm. Thus, PGC numbers increase to around 250 at embryonic day (E)9.5, to 1,000 at $\mathrm{E} 10.5$, and to 26,000 in the gonad primordia at E13.5 [11]. Massive cell biological and molecular changes 
occur in PGCs after their induction and before gonad formation. They affect the developmental potential, the cell cycle, the transcriptional program, and the epigenetic setup of the chromatin.

\section{The specification of primordial germ cells}

Once induced in the epiblast, PGC precursors start to express the transcriptional regulator Blimp1 (Prdm1) and subsequently Prdm14, two essential genes for PGC development $[12,13]$. A major function of Blimp1 in PGCs is the transcriptional repression of typical somatic genes like Hox, Snail, and others [10]. It also controls the reduction of the doubling time via downregulation of c-Myc [14]. Both Blimp1 and Prdm14 are required for the activation of the pluripotency marker Sox2, which had been suppressed in the early epiblast (Fig. 1). Its renewed transcription indicates the reacquisition of potential pluripotency $[13,15]$. With the program orchestrated by the two PRDM genes, the unique germ cell fate of the PGCs is established, and they are usually considered to be specified [15]. This implies that they are clearly bearing the characteristics of germ cells, and will continue as such, if no further influences will affect their fate. However, in order to secure this fate against external cues, a further fixation of the identity is necessary. This is achieved by epigenetic modifications of the chromatin and of the DNA, introducing inheritable marks that guarantee the commitment to a germ cell fate (Fig. 2a).

\section{The epigenetics of primordial germ cells}

PGCs arrest their cell cycle in the G2 phase and stall Pol IImediated de novo transcription relatively early after their

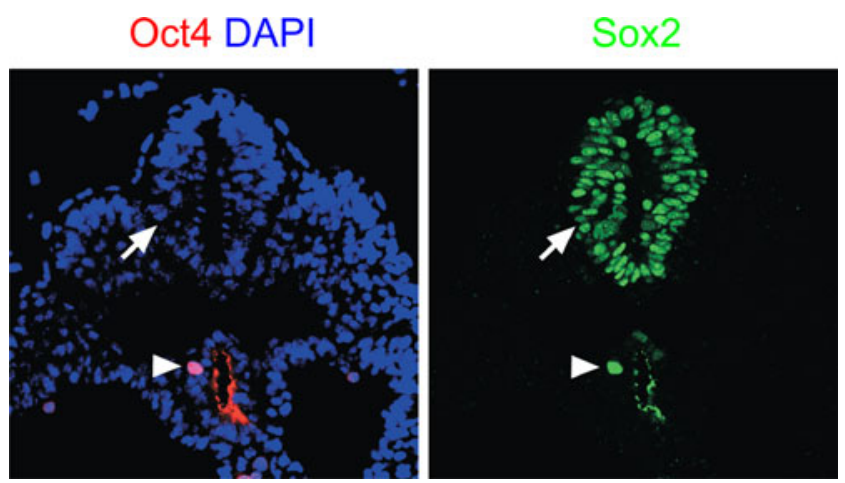

Fig. 1 PGCs reacquire potential pluripotency. PGCs (arrowhead) are the only cells in the developing embryo that co-express pluripotency markers Oct4 (in red) and Sox2 (in green). Arrow points to Sox2expressing neural tube cells. The picture represents a cross section of an E9.0 embryo specification for about $36 \mathrm{~h}$ [16]. It seems that this phase is used for initiation of significant changes in the epigenetic status. The repressive histone mark H3K9me2 now decreases progressively and becomes effectively removed. This genome-wide effect correlates with the Prdm14dependent downregulation of the histone methyltransferases GLP, which together with G9a is critical for H3K9 dimethylation $[17,18]$. In parallel, expression of the histone demethylase Jmdm2a is maintained [16, 19]. The downregulation of the methyltransferases and the maintenance of the demethylase explain the gradual loss of $\mathrm{H} 3 \mathrm{~K} 9 \mathrm{me} 2$ over time. A different suppressive histone mark, H3K27me3, is introduced by the polycomb repressive complex 2 (PRC2). PRC2 consists of the core components Ezh2, Eed, and Suz12, all of which are present in PGCs [20]. The replacement of one inhibitory modification by another changes the molecular configurations at the affected loci. H3K9me2 recruits heterochromatin protein 1 and causes DNA methylation, whereas $\mathrm{H} 3 \mathrm{~K} 27 \mathrm{me} 3$ is a histone mark conferring more plasticity $[21,22]$. PGCs have significant levels of both the activating $\mathrm{H} 3 \mathrm{~K} 4 \mathrm{me} 3$ and the repressive H3K27me3 modification, and therefore, they might in principle generate bivalent loci, i.e., configurations which are often located on developmentally critical promoter regions, and can be quickly activated in response to differentiation stimuli [23]. In PGCs, they may facilitate the epigenetic resetting of the chromatin in preparation for future differentiation steps in the genital ridges. Further histone modifications occur later, in parallel to the demethylation of DNA [24]. They comprise a transient loss of $\mathrm{H} 3 \mathrm{~K} 9 \mathrm{me} 3$ and $\mathrm{H} 3 \mathrm{~K} 27 \mathrm{me} 3$, whereas the histone variants $\mathrm{H} 4 / \mathrm{H} 2 \mathrm{AR} 3 \mathrm{me} 2 \mathrm{~s}$ and $\mathrm{H} 3 \mathrm{~K} 9 \mathrm{ac}$ are persistently lost.

In addition to the modification of histones, significant changes of DNA methylation patterns are introduced in migratory and post-migratory PGCs (Fig. 2a) [8, 16, 25, 26]. Genome-wide DNA demethylation occurs passively by repressing the DNA methyltransferases and results in a gradual loss of $5 \mathrm{mC}$ with every cell division $[17,18]$. In addition, methyl groups can also be removed from DNA directly, e.g., by employing the cytidine deaminase Aid [27]. The critical mechanism for genome-wide DNA demethylation in PGCs is DNA repair through the base excision repair (BER) pathway [28]. Only later, also repetitive regions and transposable elements become in part demethylated, while they remain highly methylated and silenced in somatic cells. Imprinting of genes is erased and becomes reestablished after sex determination to adjust the dosage according to the sex of the cells [26, 29]. Finally, the $X$ chromosome reactivation in female PGCs, which was initiated already during migration, is completed $[8,30,31]$. Taken together, the extensive remodeling of the chromatin in PGCs reprograms the epigenome in preparation for totipotency [24, 25]. 


\section{a}

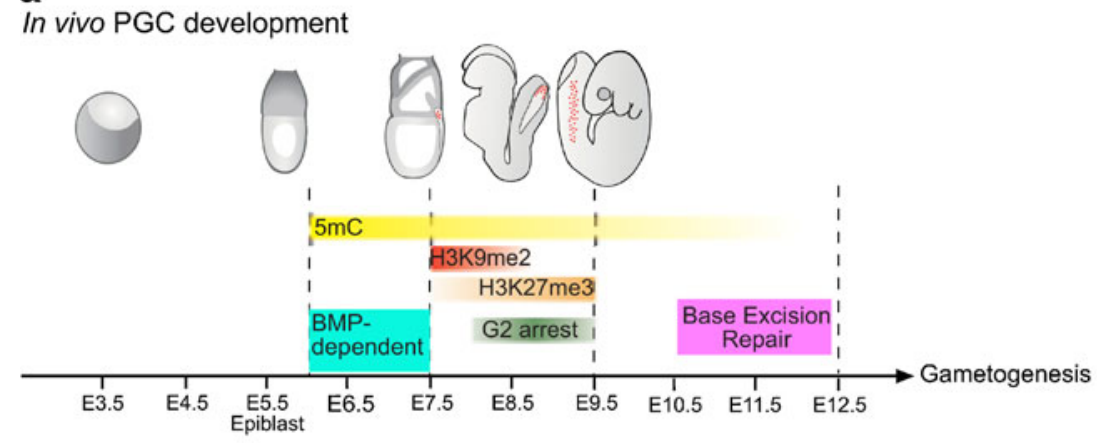

b

\section{In vitro PGC differentiation}

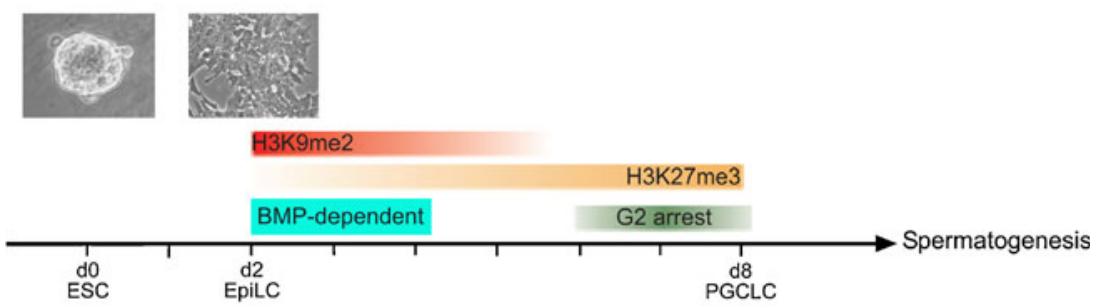

\section{C}

In vitro ESC derivation

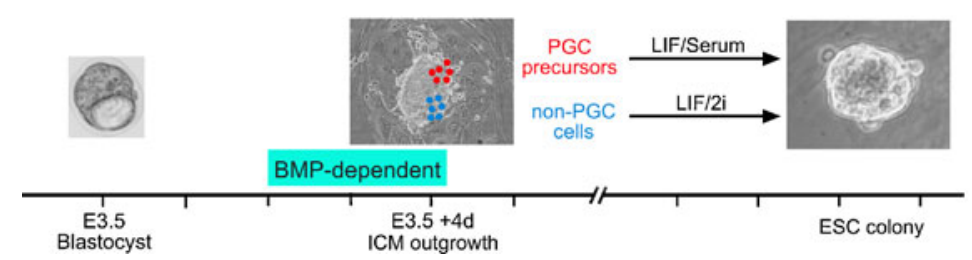

Fig. 2 Reciprocal relationship of PGCs and ESCs. a BMP4-induced PGCs (red dots) in the epiblast start epigenetic reprogramming by the erasure of DNA methylation and also changes in histone modifications while migrating in the hindgut endoderm. PGCs become transiently arrested in G2 phase of the cell cycle, and once they arrive in the genital ridges, an active DNA demethylation occurs via base excision repair-mediated mechanism. As a result, PGCs reset their genome and become ready for future gametogenesis. Modified from [28, 61]. b Germ cell differentiation in vitro from ESCs recapitulates embryonic

\section{The conversion of germ cells into pluripotent stem cells}

Early PGCs of both murine and human origin have the potential to undergo reprogramming to become pluripotent embryonic germ cells (EGCs) in vitro [32-34]. This process requires signaling of three growth factors, namely basic fibroblast growth factor (bFGF), stem cell factor (SCF), and leukemia inhibitory factor (LIF), all of which are essential for proliferation and/or survival of PGCs. The first $24 \mathrm{~h}$ of bFGF treatment are necessary and sufficient for the inhibition of further PGC differentiation and to start reprogramming to the EGC state [35]. In murine cells, this involves suppression of Blimp1, and consequently, the upregulation of its target genes, such as the pluripotency markers
PGC development [72]. Undifferentiated pluripotent ES cells, the in vitro counterparts of ICM cells, differentiate into EpiLCs and are then further induced mainly by BMPs to PGCLCs. Epigenetic reprogramming and cell cycle dynamics in PGCLCs are similar to that of native PGCs. c Blimp1-positive PGC-like precursors in the ICM outgrowth (red dots) give rise to ESCs under conventional LIF/serum conditions [83]. Alternatively, non-PGC-like cells in the outgrowth (blue dots) can directly establish ESC colonies when grown under LIF/2i conditions without germ cell-like intermediates

c-Myc, Klf4, and also Dhx38. Whereas LIF/Stat3 signaling is replaceable with bFGF during the first days of PGC conversion, it is essential to maintain the self-renewal of EGCs once pluripotency is established. Several other signaling pathways have also been reported to be involved in the conversion process. AKT signaling can promote the derivation of EGCs from cultured PGCs, partially by the inhibitory phosphorylation of GSK-3 [36]. Similarly, the conversion can be accelerated by addition of two inhibitors (2i) that block GSK3 and ERK signaling pathways [37]. Deficiencies in p53 and PTEN, two critical tumor suppressor genes, are associated with an increase of the potential for EGC derivation [36, 38, 39]. Chromatin modifiers like trichostatin A can inhibit histone deacetylases and boost 
the derivation of EGCs without using bFGF [40]. Noteworthy, the complete pluripotency circuit is not established in PGCs, although Oct4, Sox2, and Nanog are expressed $[41,42]$. Again, the key difference seems to be the presence of Blimp1 and, therefore, the suppression of other pluripotency-related genes like Klf4 and c-Myc [43]. Early during reprogramming to EGCs, Blimp1 expression is lost, the pluripotency circuit becomes dominant, and EGCs can be established in culture $[40,44]$. The possibility to generate pluripotent stem cells from human fetal gonads was first described in 1998, simultaneously with the first isolations of pluripotent human embryonic stem cells (ESCs) [34, 45].

Increasing evidence indicates the possibility that also postnatal testicular cells can reacquire pluripotency, sharing this characteristic with their embryonic PGC ancestors. In testes, a unipotent stem cell population, the spermatogonial stem cells ( $\mathrm{SSCs}$ ), functions as the origin for the differentiation of spermatozoa. SSCs are dominated by a spermatogonial transcription program and express low levels of core pluripotency genes such as Oct4, Klf4, Myc, and Rex-1, but no appreciable levels of Sox2 and Nanog [46, 47]. Under appropriate growth conditions, pluripotent stem cells, previously designated among others germline-derived pluripotent stem cells (gPSCs), can be derived from the SSCs of neonatal or adult mice, and possibly also humans [46-54]. Importantly, the in vitro reprogramming of SSCs to gPSCs is independent of the transfer of exogenous, pluripotencyrelated genes [48]. The whole issue of testis-derived pluripotent stem cells of human origin is still under debate [55, 56]. However, there is generally no serious doubt that they will be available in a not so far future [56]. Major activities focus on such human testis-derived pluripotent stem cells, obtainable from biopsies and without gene transfer, since they may open a realistic perspective for medical applications $[57,58]$. However, human gPSCs will require the availability of healthy testes with an intact spermatogenesis program. Therefore, they are unlikely to be of use for the generation of patient-specific germ cells applicable in reproductive medicine.

\section{The conversion of pluripotent stem cells into PGCs and gametes}

The generation of PGCs and/or gametes in culture would facilitate the access to cells resembling the rare PGCs of early stages. It may be a prerequisite for the dissection of the various cell biological and molecular steps of PGC development. It would also allow for the first time to study human PGC development in more detail [59]. Several attempts were undertaken to derive PGCs or later stages of germ cells from murine or human pluripotent cells, in particular from ESCs or epiblast stem cells (EpiSCs; reviewed in [60,
61]). The differentiation efficiency of murine ESCs towards germ cells initially turned out to be quite low, the underlying molecular mechanisms did not become clear, and the putative cellular intermediates could not be characterized. In some cases, fully differentiated male haploid germ cells were obtained and successfully applied for fertilization. However, offspring died prematurely in embryonic or postnatal stages [62-65]. Human PGC-like cells could be obtained from pluripotent ESCs or induced pluripotent cells (iPSCs; for review, see [66, 67]), applying the right growth conditions, including also co-culture with human fetal gonadal cells [59]. Haploid gamete development required genetic manipulations, in particular the modulation of genes of the DAZ gene family [68-70].

In the embryo, PGCs derive from the epiblast cells, all of which have the potential to differentiate to PGCs in response to BMP signaling [2]. Therefore, EpiSCs, the self-renewing in vitro counterparts of the epiblast, were considered as a starting point for in vitro PGC generation. While selfrenewing in culture, EpiSCs delineated PGC precursors recognizable by the expression of a Blimp1-GFP reporter gene [71]. These precursors could differentiate into committed PGCs, expressing typical marker genes including Oct4, SSEA1, Prdm14, Nanos3, Dnd1, and Stella. Indeed, cultured EpiSCs were continuously fluctuating between selfrenewing and differentiating states (Blimp $1^{-} / \mathrm{Oct}^{+}$versus Blimp $\left.1^{+} / \mathrm{Oct}^{+}\right)$, and the latter could proceed to a germlinecommitted state $\left(\mathrm{Blimp}^{+} / \mathrm{Oct}^{+} / \mathrm{Stella}^{+}\right)$. The differentiation was BMP4-dependent. Epigenetic reprogramming was indicated by a downregulation of H3K9me2 and GLP and the upregulation of $\mathrm{H} 3 \mathrm{~K} 27 \mathrm{me} 3$, similar to nascent PGCs. These Stella ${ }^{+}$cells could de-differentiate to EGCs under appropriate growth conditions, or proliferate and express Mvh and Sycp3 if co-cultured with E12.5 female gonadal cells, and occasionally differentiated further to oocyte-like structures. In general, the efficiency of germ cell derivation from EpiSCs was relatively low, with less than one oocyte per 3,000 plated Stella ${ }^{+}$cells, and the underlying molecular mechanism was not evident.

Following closely the in vivo development of PGCs, Hayashi et al. [72] established a robust method to derive functional germ cells from murine ESCs via epiblast-like intermediates (Fig. 2b). First, ESCs were cultured in serumand feeder-free conditions in the presence of LIF and two inhibitors (LIF/2i conditions), which lead to uniform ESCs resembling the cells of the inner cell mass (ICM) or the preimplantation epiblast [73]. Upon LIF/2i withdrawal and addition of growth factors (activin and bFGF), a differentiation toward an epiblast-like state was induced. These intermediates, designated epiblast-like cells (EpiLCs), were explicitly different from EpiSCs in terms of gene expression profile and resembled more closely embryonic cells of the pre-implantation epiblast. The 
EpiLCs were further induced to PGCs by BMP4, LIF, SCF, BMP8b, and EGF in floating condition. Six days after induction AP-, Blimp1-, and Stella-positive PGC-like cells (PGCLCs) emerged at the periphery of the cell aggregates with a relatively high efficiency. Like specified native PGCs, these committed PGCLCs manifested genetic and epigenetic signatures and cell cycle dynamics similar to those of E9.5 PGCs [16]. In order to test the developmental potential of PGCLCs, they were transplanted into testes of infertile mice. Here, they differentiated into sperm, which could fertilize oocytes, and give rise to a healthy offspring. It is not clear yet if this differentiation protocol involves also BER-mediated DNA demethylation as would be the case for native PGCs. Additionally, the potential of this protocol to induce female differentiation from ES cells would be of interest. Global gene expression analysis revealed that PGCLC induction from ES cells is a reproducible, directional, and progressive process. This novel protocol for in vitro differentiation recapitulates the in vivo specification and epigenetic reprogramming of germ cell and manifests several steps of PGC development. In the future, this paradigm will be useful to derive high numbers of germ cells and study the dynamics of their genetic and epigenetic status. In general, in vitro differentiation of germ cells from pluripotent stem cells is feasible. It involves a multistep procedure including induction, genetic and epigenetic reprogramming, and alteration in cell cycle of PGCs, as well as mitosis versus meiosis decision making and maturation of gametes. Progression through the initial steps is paved in vitro using a right inducing cocktail of growth factors, while fulfilling gametogenesis requires an appropriate microenvironment, which can possibly be provided by gonadal cells in co-culture.

\section{Is pluripotency achieved via a germ cell-like intermediate?}

Although ESCs have raised a tremendous amount of attention during the last decades, the in vivo origin of ESCs remained a point of discussion [74, 75]. It has recently become clear that ESCs originate only from a small subset of cells in the ICM, when cultured under standard conditions in serum and LIF supplement medium [76]. Several lines of evidence provoked the hypothesis that ESCs might derive from PGC-like cells present in the ICM outgrowth. First, explanted cells from the ICM transiently express PGCrelated genes, including Blimp1, Prdm14, Stella, Fragilis, Lin28, c-kit, and Mvh [75, 77, 78]. Second, specified PGCs are the only cells in the early embryo that maintain (Oct4 and Nanog) or reacquire (Sox2) the expression of pluripotency-associated genes. Third, PGCs can be induced to reprogram to pluripotency in vitro, and resulting EGCs are in most respects indistinguishable from ESCs. Fourth,
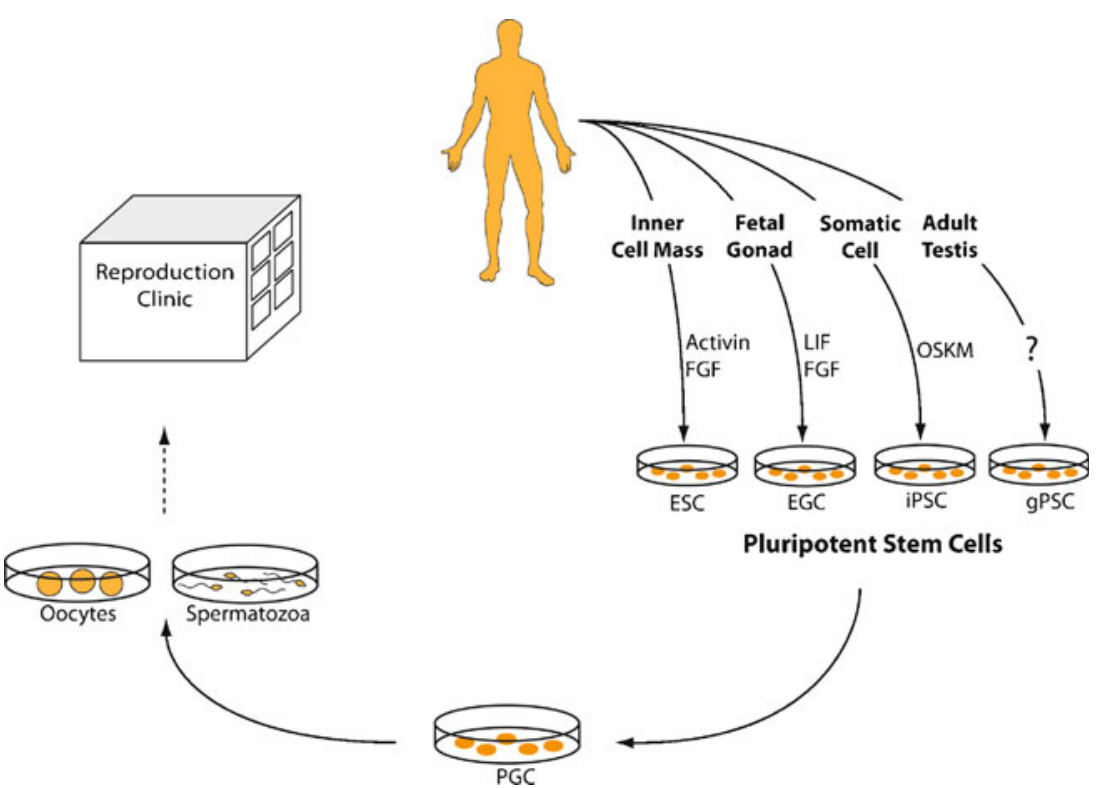

Fig. 3 The application of human pluripotent stem cells for reproductive medicine. Pluripotent human cells can be derived from the inner cell mass of early embryos under activin/FGF conditions (ESC), from fetal gonads under LIF/FGF conditions $(E G C)$, from somatic cells using three or four transcription factors (iPSC), and possibly from adult testis biopsies gPSC, although the latter has only been shown in the mouse model so far. As discussed in the text, only the somatic cells offer a perspective for the derivation of patient-specific PGCs, the subsequent differentiation into oocytes or spermatozoa in vitro, and their use for fertilization. However, many hurdles have to be taken before this method would be applicable in the clinic, including vectorfree induction of pluripotency and a stringent quality control of the culture conditions with regard to mutation accumulation, epigenetic aberrations, and genomic integrity 
the development of both pluripotent ESCs and PGCs requires BMP signaling [79-82]. Fifth, gPSCs can be derived from unipotent SSCs of the adult mouse testis [48].

Recently, Chu et al. used a Blimp1-reporter mouse line in combination with single cell gene expression profiling to look systematically for a potential link between PGCs and ESCs (Fig. 2c) [83]. They detected genetically marked Blimp1-positive PGC precursors in the outgrowth of in vitro-cultured blastocysts, which gave rise to the majority of pluripotent ESCs in the presence of LIF and serum. The culture of Blimp1-negative, and therefore non-PGC-related cells from the ICM on the other hand, required LIF/2i conditions for the establishment of ESCs (Fig. 2c). These striking results indicate that not Blimp1 expression as such is the key prerequisite for the generation of ESCs from the ICM of the mouse. The $2 \mathrm{i}$ factors seem to allow a more direct generation of ESCs by blocking differentiation into the extraembryonic endoderm lineage or possibly by suppressing a somatic program [76]. Thus, depending on the culture condition, ESCs can be established with or without a germ cell-like intermediate. With this information in mind, it would be interesting to ask if also the generation of iPSCs from fibroblasts might pass through a germ celllike state. Indeed, it was found that the PGC markers Blimp1, Stella, and Fragilis start to express earlier after viral transduction than pluripotency markers [77]. However, further work is needed to fully understand the significance of this observation.

\section{In vitro made patient-specific germ cells in reproductive medicine?}

The extensive possibilities for a reciprocal conversion of cell types in vitro may raise questions about potential applications in reproductive medicine. Is it realistic to envision in vitro made, patient-specific spermatozoa or oocytes for infertility treatment? Theoretically, it is conceivable to connect the described in vitro methods to derive patient-specific pluripotent cells, differentiate them into PGCs, generate gametes, perform in vitro fertilization, and retransfer human embryos to a natural or surrogate mother (Fig. 3). Such a use of in vitrogenerated gametes for medical purposes would obviously raise a number of ethical issues. Pluripotent cells which could be approved as a source for human germ cells are currently not available for several reasons. Firstly, human ESCs and EGCs are generated from parts of embryos, the inner cell mass and fetal gonad, respectively, and are therefore unacceptable for medical applications. Secondly, iPSCs are generated by gene transfer and, therefore, cannot be approved for therapeutic purposes. Thirdly, the derivation of pluripotent gPSCs has so far not been successfull from human testis biopsies $[55,56]$. If they would become available, they might represent an acceptable alternative for therapeutic purposes, most probably, however, excluding the generation of patient-specific germ cells. In any case, the generation of gametes from pluripotent cells requires extensive culturing and passaging in culture, where they would be exposed to a whole battery of highly effective factors and agents with non-overseeable influences. Most probably, the last steps of gametogenesis would require gonad material to create a suitable developmental niche. Such a complex in vitro scenario is only vaguely controllable, with multiple possibilities for mutations, DNA damage, and chromosomal aberrations. To consider such cells for use in reproductive medicine and, thus, with consequences for following generations would trespass ethical standards in an unprecedented dimension and would be legally unacceptable in most countries.

\section{Conclusion}

PGCs are considered unipotent, since they can only give rise to the gametes. At the same time, they are the only cells of the body which will finally generate a totipotent cell, when the haploid gametes fuse to form the one-cell embryo. ESCs and EpiSCs are pluripotent stem cells derived from the murine epiblast briefly before and after implantation, respectively. Derivation of ESCs from the ICM is a process that involves a germ cell-like intermediate, although it can be bypassed in appropriate growth conditions [83]. Early PGCs are the only embryonic cells, and SSCs are the only postnatal cells which reacquire the potential for pluripotency and can give rise to self-renewing pluripotent stem cells, EGCs, and gPSCs, respectively. Among the extensive developmental possibilities of all pluripotent stem cells is also the capacity to differentiate into PGCs. The close developmental relationship between peri-implantation cells from the embryo and pluripotent stem cells may be the reason that they can be converted from one into the other by using appropriate growth factors, cytokines, or small chemical inhibitors. Thus, ESCs can develop into PGCs, PGCs into EGCs, and EpiSCs into either ESCs or PGCs [32, 33, 71, 84, 85]. Through the forced expression of only four critical genes, it is possible to convert basically any somatic cell into a pluripotent iPS cell and then again derive a large variety of differentiated cells, including PGCs, by the modulation of growth conditions [66, 86]. All these extensive possibilities are based on major modulations of the transcriptome and the epigenome. Understanding these will establish the basis for a novel level of knowledge in stem and germ cell biology and may or may not open a perspective to molecular medicine. 


\section{References}

1. De Felici M, Farini D (2012) The control of cell cycle in mouse primordial germ cells: old and new players. Curr Pharm Des $18: 233-244$

2. Ohinata Y, Ohta H, Shigeta M, Yamanaka K, Wakayama T, Saitou M (2009) A signaling principle for the specification of the germ cell lineage in mice. Cell 137:571-584

3. Hopf C, Viebahn C, Puschel B (2011) BMP signals and the transcriptional repressor BLIMP1 during germline segregation in the mammalian embryo. Dev Genes Evol 221:209-223

4. de Sousa Lopes SM, Hayashi K, Surani MA (2007) Proximal visceral endoderm and extraembryonic ectoderm regulate the formation of primordial germ cell precursors. BMC Dev Biol 7:140

5. Saga Y (2008) Mouse germ cell development during embryogenesis. Curr Opin Genet Dev 18:337-341

6. Saitou M (2009) Germ cell specification in mice. Curr Opin Genet Dev 19:386-395

7. Saitou M (2009) Specification of the germ cell lineage in mice. Front Biosci 14:1068-1087

8. Saitou M, Kagiwada S, Kurimoto K (2012) Epigenetic reprogramming in mouse pre-implantation development and primordial germ cells. Development 139:15-31

9. McLaren A (2000) Establishment of the germ cell lineage in mammals. J Cell Physiol 182:141-143

10. McLaren A, Lawson KA (2005) How is the mouse germ-cell lineage established? Differentiation 73:435-437

11. Tam PP, Snow MH (1981) Proliferation and migration of primordial germ cells during compensatory growth in mouse embryos. J Embryol Exp Morphol 64:133-147

12. Ohinata Y, Payer B, O'Carroll D, Ancelin K, Ono Y, Sano M, Barton SC, Obukhanych T, Nussenzweig M, Tarakhovsky A et al (2005) Blimp1 is a critical determinant of the germ cell lineage in mice. Nature 436:207-213

13. Yamaji M, Seki Y, Kurimoto K, Yabuta Y, Yuasa M, Shigeta M, Yamanaka K, Ohinata Y, Saitou M (2008) Critical function of Prdm14 for the establishment of the germ cell lineage in mice. Nat Genet 40:1016-1022

14. Lin Y, Wong K, Calame K (1997) Repression of c-myc transcription by Blimp-1, an inducer of terminal $\mathrm{B}$ cell differentiation. Science 276:596-599

15. Kurimoto K, Yamaji M, Seki Y, Saitou M (2008) Specification of the germ cell lineage in mice: a process orchestrated by the PRdomain proteins, Blimp1 and Prdm14. Cell Cycle 7:3514-3518

16. Seki Y, Yamaji M, Yabuta Y, Sano M, Shigeta M, Matsui Y, Saga Y, Tachibana M, Shinkai Y, Saitou M (2007) Cellular dynamics associated with the genome-wide epigenetic reprogramming in migrating primordial germ cells in mice. Development 134:2627-2638

17. Seki Y, Hayashi K, Itoh K, Mizugaki M, Saitou M, Matsui Y (2005) Extensive and orderly reprogramming of genome-wide chromatin modifications associated with specification and early development of germ cells in mice. Dev Biol 278:440-458

18. Kurimoto K, Yabuta Y, Ohinata Y, Shigeta M, Yamanaka K, Saitou M (2008) Complex genome-wide transcription dynamics orchestrated by Blimp1 for the specification of the germ cell lineage in mice. Genes Dev 22:1617-1635

19. Yamane K, Toumazou C, Tsukada Y, Erdjument-Bromage H, Tempst P, Wong J, Zhang Y (2006) JHDM2A, a JmjCcontaining $\mathrm{H} 3 \mathrm{~K} 9$ demethylase, facilitates transcription activation by androgen receptor. Cell 125:483-495

20. Yabuta Y, Kurimoto K, Ohinata Y, Seki Y, Saitou M (2006) Gene expression dynamics during germline specification in mice identified by quantitative single-cell gene expression profiling. Biol Reprod 75:705-716
21. Hawkins RD, Hon GC, Yang C, Antosiewicz-Bourget JE, Lee LK, Ngo QM, Klugman S, Ching KA, Edsall LE, Ye Z et al (2011) Dynamic chromatin states in human ES cells reveal potential regulatory sequences and genes involved in pluripotency. Cell Res 21:1393-1409

22. Smallwood A, Esteve PO, Pradhan S, Carey M (2007) Functional cooperation between HP1 and DNMT1 mediates gene silencing. Genes Dev 21:1169-1178

23. Bernstein BE, Mikkelsen TS, Xie X, Kamal M, Huebert DJ, Cuff J, Fry B, Meissner A, Wernig M, Plath K et al (2006) A bivalent chromatin structure marks key developmental genes in embryonic stem cells. Cell 125:315-326

24. Hajkova P, Ancelin K, Waldmann T, Lacoste N, Lange UC, Cesari F, Lee C, Almouzni G, Schneider R, Surani MA (2008) Chromatin dynamics during epigenetic reprogramming in the mouse germ line. Nature 452:877-881

25. Hajkova P (2011) Epigenetic reprogramming in the germline: towards the ground state of the epigenome. Philos Trans R Soc Lond B Biol Sci 366:2266-2273

26. Hackett JA, Zylicz JJ, Surani MA (2012) Parallel mechanisms of epigenetic reprogramming in the germline. Trends Genet 28 (4):164-174

27. Popp C, Dean W, Feng S, Cokus SJ, Andrews S, Pellegrini M, Jacobsen SE, Reik W (2010) Genome-wide erasure of DNA methylation in mouse primordial germ cells is affected by AID deficiency. Nature 463:1101-1105

28. Hajkova P, Jeffries SJ, Lee C, Miller N, Jackson SP, Surani MA (2010) Genome-wide reprogramming in the mouse germ line entails the base excision repair pathway. Science 329:78-82

29. Bartolomei MS, Ferguson-Smith AC (2011) Mammalian genomic imprinting. Cold Spring Harb Perspect Biol 3:a002592

30. Sasaki H, Matsui Y (2008) Epigenetic events in mammalian germcell development: reprogramming and beyond. Nat Rev Genet 9:129-140

31. Mochizuki K, Matsui Y (2010) Epigenetic profiles in primordial germ cells: global modulation and fine tuning of the epigenome for acquisition of totipotency. Dev Growth Differ 52:517-525

32. Resnick JL, Bixler LS, Cheng L, Donovan PJ (1992) Long-term proliferation of mouse primordial germ cells in culture. Nature 359:550-551

33. Matsui Y, Zsebo K, Hogan BL (1992) Derivation of pluripotential embryonic stem cells from murine primordial germ cells in culture. Cell 70:841-847

34. Shamblott MJ, Axelman J, Wang S, Bugg EM, Littlefield JW, Donovan PJ, Blumenthal PD, Huggins GR, Gearhart JD (1998) Derivation of pluripotent stem cells from cultured human primordial germ cells. Proc Natl Acad Sci USA 95:13726-13731

35. Durcova-Hills G, Adams IR, Barton SC, Surani MA, McLaren A (2006) The role of exogenous fibroblast growth factor-2 on the reprogramming of primordial germ cells into pluripotent stem cells. Stem Cells 24:1441-1449

36. Kimura T, Suzuki A, Fujita Y, Yomogida K, Lomeli H, Asada N, Ikeuchi M, Nagy A, Mak TW, Nakano T (2003) Conditional loss of PTEN leads to testicular teratoma and enhances embryonic germ cell production. Development 130:1691-1700

37. Leitch HG, Blair K, Mansfield W, Ayetey H, Humphreys P, Nichols J, Surani MA, Smith A (2010) Embryonic germ cells from mice and rats exhibit properties consistent with a generic pluripotent ground state. Development 137:2279-2287

38. Moe-Behrens GH, Klinger FG, Eskild W, Grotmol T, Haugen TB, De Felici M (2003) Akt/PTEN signaling mediates estrogendependent proliferation of primordial germ cells in vitro. Mol Endocrinol 17:2630-2638

39. Deng W, Xu Y (2009) Genome integrity: linking pluripotency and tumorgenicity. Trends Genet 25:425-427 
40. Durcova-Hills G, Tang F, Doody G, Tooze R, Surani MA (2008) Reprogramming primordial germ cells into pluripotent stem cells. PLoS One 3:e3531

41. Ng HH, Surani MA (2011) The transcriptional and signalling networks of pluripotency. Nat Cell Biol 13:490-496

42. Young RA (2011) Control of the embryonic stem cell state. Cell 144:940-954

43. Boyer LA, Lee TI, Cole MF, Johnstone SE, Levine SS, Zucker JP, Guenther MG, Kumar RM, Murray HL, Jenner RG et al (2005) Core transcriptional regulatory circuitry in human embryonic stem cells. Cell 122:947-956

44. Tee WW, Pardo M, Theunissen TW, Yu L, Choudhary JS, Hajkova P, Surani MA (2010) Prmt5 is essential for early mouse development and acts in the cytoplasm to maintain ES cell pluripotency. Genes Dev 24:2772-2777

45. Thomson JA, Itskovitz-Eldor J, Shapiro SS, Waknitz MA, Swiergiel JJ, Marshall VS, Jones JM (1998) Embryonic stem cell lines derived from human blastocysts. Science 282:1145-1147

46. Kanatsu-Shinohara M, Inoue K, Lee J, Yoshimoto M, Ogonuki N, Miki H, Baba S, Kato T, Kazuki Y, Toyokuni S et al (2004) Generation of pluripotent stem cells from neonatal mouse testis. Cell 119:1001-1012

47. Kanatsu-Shinohara M, Lee J, Inoue K, Ogonuki N, Miki H, Toyokuni S, Ikawa M, Nakamura T, Ogura A, Shinohara T (2008) Pluripotency of a single spermatogonial stem cell in mice. Biol Reprod 78:681-687

48. Ko K, Tapia N, Wu G, Kim JB, Bravo MJ, Sasse P, Glaser T, Ruau D, Han DW, Greber B et al (2009) Induction of pluripotency in adult unipotent germline stem cells. Cell Stem Cell 5:87-96

49. Conrad S, Renninger M, Hennenlotter J, Wiesner T, Just L, Bonin M, Aicher W, Buhring HJ, Mattheus U, Mack A et al (2008) Generation of pluripotent stem cells from adult human testis. Nature 456:344-349

50. Seandel M, James D, Shmelkov SV, Falciatori I, Kim J, Chavala S, Scherr DS, Zhang F, Torres R, Gale NW et al (2007) Generation of functional multipotent adult stem cells from GPR125+ germline progenitors. Nature 449:346-350

51. Ko K, Wu G, Arauzo-Bravo MJ, Kim J, Francine J, Greber B, Muhlisch J, Joo JY, Sabour D, Fruhwald MC, et al. (2012) Autologous pluripotent stem cells generated from adult mouse testicular biopsy. Stem Cell Rev and Rep, doi:10.1007/s12015-011-9307-x

52. Golestaneh N, Kokkinaki M, Pant D, Jiang J, DeStefano D, Fernandez-Bueno C, Rone JD, Haddad BR, Gallicano GI, Dym M (2009) Pluripotent stem cells derived from adult human testes. Stem Cells Dev 18:1115-1126

53. Kossack N, Meneses J, Shefi S, Nguyen HN, Chavez S, Nicholas C, Gromoll J, Turek PJ, Reijo-Pera RA (2009) Isolation and characterization of pluripotent human spermatogonial stem cellderived cells. Stem Cells 27:138-149

54. Mizrak SC, Chikhovskaya JV, Sadri-Ardekani H, van Daalen S, Korver CM, Hovingh SE, Roepers-Gajadien HL, Raya A, Fluiter K, de Reijke TM et al (2010) Embryonic stem cell-like cells derived from adult human testis. Hum Reprod 25:158-167

55. Tapia N, Arauzo-Bravo MJ, Ko K, Scholer HR (2011) Concise review: challenging the pluripotency of human testis-derived ESClike cells. Stem Cells 29:1165-1169

56. Ko K, Reinhardt P, Tapia N, Schneider RK, Arauzo-Bravo MJ, Han DW, Greber B, Kim J, Kliesch S, Zenke M et al (2011) Brief report: evaluating the potential of putative pluripotent cells derived from human testis. Stem Cells 29:1304-1309

57. Zhu S, Wei W, Ding S (2011) Chemical strategies for stem cell biology and regenerative medicine. Annu Rev Biomed Eng 13:73-90

58. Efe JA, Ding S (2011) The evolving biology of small molecules: controlling cell fate and identity. Philos Trans R Soc Lond B Biol Sci 366:2208-2221
59. Park TS, Galic Z, Conway AE, Lindgren A, van Handel BJ, Magnusson M, Richter L, Teitell MA, Mikkola HK, Lowry WE et al (2009) Derivation of primordial germ cells from human embryonic and induced pluripotent stem cells is significantly improved by coculture with human fetal gonadal cells. Stem Cells 27:783-795

60. Daley GQ (2007) Gametes from embryonic stem cells: a cup half empty or half full? Science 316:409-410

61. Saitou M, Yamaji M (2010) Germ cell specification in mice: signaling, transcription regulation, and epigenetic consequences. Reproduction 139:931-942

62. Nayernia K, Nolte J, Michelmann HW, Lee JH, Rathsack K, Drusenheimer N, Dev A, Wulf G, Ehrmann IE, Elliott DJ et al (2006) In vitro-differentiated embryonic stem cells give rise to male gametes that can generate offspring mice. Dev Cell 11:125-132

63. Geijsen N, Horoschak M, Kim K, Gribnau J, Eggan K, Daley GQ (2004) Derivation of embryonic germ cells and male gametes from embryonic stem cells. Nature 427:148-154

64. Toyooka Y, Tsunekawa N, Akasu R, Noce T (2003) Embryonic stem cells can form germ cells in vitro. Proc Natl Acad Sci USA 100:11457-11462

65. Hubner K, Fuhrmann G, Christenson LK, Kehler J, Reinbold R, De La Fuente R, Wood J, Strauss JF 3rd, Boiani M, Scholer HR (2003) Derivation of oocytes from mouse embryonic stem cells. Science 300:1251-1256

66. Lewitzky M, Yamanaka S (2007) Reprogramming somatic cells towards pluripotency by defined factors. Curr Opin Biotechnol $18: 467-473$

67. Stadtfeld M, Hochedlinger K (2010) Induced pluripotency: history, mechanisms, and applications. Genes Dev 24:2239-2263

68. Kee K, Angeles VT, Flores M, Nguyen HN, Reijo Pera RA (2009) Human DAZL, DAZ and BOULE genes modulate primordial germ-cell and haploid gamete formation. Nature 462:222-225

69. Panula S, Medrano JV, Kee K, Bergstrom R, Nguyen HN, Byers B, Wilson KD, Wu JC, Simon C, Hovatta O et al (2012) Human germ cell differentiation from fetal- and adult-derived induced pluripotent stem cells. Hum Mol Genet 20:752-762

70. Yu Z, Ji P, Cao J, Zhu S, Li Y, Zheng L, Chen X, Feng L (2009) Dazl promotes germ cell differentiation from embryonic stem cells. J Mol Cell Biol 1:93-103

71. Hayashi K, Surani MA (2009) Self-renewing epiblast stem cells exhibit continual delineation of germ cells with epigenetic reprogramming in vitro. Development 136:3549-3556

72. Hayashi K, Ohta H, Kurimoto K, Aramaki S, Saitou M (2011) Reconstitution of the mouse germ cell specification pathway in culture by pluripotent stem cells. Cell 146:519-532

73. Ying QL, Wray J, Nichols J, Batlle-Morera L, Doble B, Woodgett J, Cohen P, Smith A (2008) The ground state of embryonic stem cell self-renewal. Nature 453:519-523

74. Nichols J, Smith A (2011) The origin and identity of embryonic stem cells. Development 138:3-8

75. Zwaka TP, Thomson JA (2005) A germ cell origin of embryonic stem cells? Development 132:227-233

76. Nichols J, Silva J, Roode M, Smith A (2009) Suppression of Erk signalling promotes ground state pluripotency in the mouse embryo. Development 136:3215-3222

77. Xu X, Pantakani DV, Luhrig S, Tan X, Khromov T, Nolte J, Dressel R, Zechner U, Engel W (2011) Stage-specific germ-cell marker genes are expressed in all mouse pluripotent cell types and emerge early during induced pluripotency. PLoS One 6:e22413

78. Tang F, Barbacioru C, Bao S, Lee C, Nordman E, Wang X, Lao K, Surani MA (2010) Tracing the derivation of embryonic stem cells from the inner cell mass by single-cell RNA-Seq analysis. Cell Stem Cell 6:468-478 
79. Dudley B, Palumbo C, Nalepka J, Molyneaux K (2010) BMP signaling controls formation of a primordial germ cell niche within the early genital ridges. Dev Biol 343:84-93

80. Childs AJ, Kinnell HL, Collins CS, Hogg K, Bayne RA, Green SJ, McNeilly AS, Anderson RA (2010) BMP signaling in the human fetal ovary is developmentally regulated and promotes primordial germ cell apoptosis. Stem Cells 28:1368-1378

81. Wagner TU (2007) Bone morphogenetic protein signaling in stem cells - one signal, many consequences. FEBS J 274:2968-2976

82. Dudley BM, Runyan C, Takeuchi Y, Schaible K, Molyneaux K (2007) BMP signaling regulates PGC numbers and motility in organ culture. Mech Dev 124:68-77
83. Chu LF, Surani MA, Jaenisch R, Zwaka TP (2011) Blimp1 expression predicts embryonic stem cell development in vitro. Curr Biol 21:1759-1765

84. Wei W, Qing TT, Ye X, Liu HS, Zhang DH, Yang WF, Deng HK (2008) Primordial germ cell specification from embryonic stem cells. Plos One 3(12):e4013

85. Guo G, Yang J, Nichols J, Hall JS, Eyres I, Mansfield W, Smith A (2009) Klf4 reverts developmentally programmed restriction of ground state pluripotency. Development 136:1063-1069

86. Imamura M, Aoi T, Tokumasu A, Mise N, Abe K, Yamanaka S, Noce T (2010) Induction of primordial germ cells from mouse induced pluripotent stem cells derived from adult hepatocytes. Mol Reprod Dev 77:802-811 